\title{
STATUS OF Orobanche cernua Loefl. AND WEEDS IN SUNFLOWER PRODUCTION IN TURKEY
}

\author{
Demirci, M. ${ }^{*}$, Kaya, Y. ${ }^{1}$ \\ ${ }^{1}$ Trakya Agricultural Research Institute, P.O.Box: 16, 22100 Edirne, Turkey \\ ${ }^{2}$ Agrobest Grup Co, Kemalpasa-Izmir, Turkey
}

Received: July 15, 2009 Accepted: November 10, 2009

SUMMARY

Broomrape $(O$. cernua) is one of the most serious hindrances in sunflower production throughout Turkey and East Europe. Previous and recent studies have shown that imidazolinone (IMI) herbicides applied on Imidazolinone-resistant sunflowers effectively control $O$. cernua by rapid absorbtion, translocation and accumulation in the root-attached parasite. However, susceptibility level of susceptible sunflower cultivars to herbicides has been an obstacle in the application of these herbicides. Preliminary studies have been conducted with susceptible sunflower cultivars. Best results were obtained with a single foliar treatment with Imazamox (35 g/l) + imazapyr (15 g/l), $43.75+18.75 \mathrm{~g} / \mathrm{ha}$ was applied on imidazolinone-resistant sunflower plants at 8-10 true leaf stage. The treatment caused serious damage to susceptible sunflower plants but no damage was observed on IMI resistant cultivars since they completely controlled O. cernua, resulting in a significant increase in sunflower seed yield over the non-treated control. In addition, the same treatment controlled key weeds that seriously affect sunflower production. Broomrape (O.cernua) and weeds have infested sunflowers and significantly reduced yield in the observed sunflower production area. But, use of IMI resistant and broomrape tolerant hybrids has effectively suppressed and decreased weed population and epidemics in recent years.

Key words: Orobanche cernua, weed control, imidazolinone herbicides, sunflower

\section{INTRODUCTION}

Oil sunflower has been an important field crop in Turkey since it was introduced by the Turkish immigrants from East European countries such as Bulgaria, Romania, etc. in the second half of the 1940s. As oil source, sunflower is important for Turkey as it is the most preferred plant oil among consumers and it is a main crop in the rotation systems in Trakya region which is the European part of Turkey and which supports at least $75 \%$ of the total sunflower productions in Turkey.

* Corresponding author: e-mail: msdemirci@gmail.com 
Broomrape (Orobanche cernua Loefl.) is the most important problem in sunflower production, reducing its seed yield and negatively affecting other sunflower traits . Genetic resistance to broomrape, originating primarily from wild Helianthus species was introduced into sunflower cultivars from early sunflower breeding programs in the former Soviet Union (Pustovoit, 1966). In the past, broomrape races A, B, C, D and E overcame the resistance provided by $\mathrm{Or}_{1}, \mathrm{Or}_{2}, \mathrm{Or}_{3}, \mathrm{Or}_{4}$ and $\mathrm{Or}_{5}$ genes, influencing severely the sunflower production acreage in Turkey and some European countries from 1958 to 1985 (Gagne et al., 1998). The widespread use of resistant cultivars usually leads to the occurrence of new races of the parasite that overcome the resistance genes roughly each 20 years (Škorić, 1988; Kaya 2003).

The first occurrence of broomrape epiphytotics in the sunflower production in Trakya region of Turkey was in the early 1960s (Ozhatay, 1973). The sunflower production was decreased dramatically and the problem was solved with introducing V-1646 and V-8931, open pollinated cultivars from Russia in 1965, which were resistant to these races. Similarly, broomrape epiphytotics brole out in sunflowers in Spain (Domingez et al., 1996), Balkan countries and the former Soviet Union (Aćimović, 1980; Vranceanu, 1980). He parasite occurred in these countries roughly at the same time.

Broomrape again became a problem in the early 1980s and studies showed that a new race overcame the protection provided by the genes confering resistance to A, B, C, and D races in Turkey (Uludere, 1988; Bulbul, 1991; Aydin, 1996), Balkan countries (Mihaljčević, 1996; Pacurianu-Joita et al., 1998; Shindrova et al., 1998) and Spain (Melero-Vara et al., 1989). After introducing resistant sunflower hybrids from Romania and some other countries in 1983s, which contained the $\mathrm{Or}_{5}$ gene, the race $\mathrm{E}$ disappeared from the sunflower production areas in Trakya region (Kaya, 2004).

After a period of immunity, a new Orobanche race called race $\mathrm{F}$ was determined in Turkey (Kaya, 2003), Romania (Pacurianu-Joita et al., 1998) and in some areas of Spain (Alonso, 1996; Ruso et al., 1996; Sukno et al., 1999a, 1999b; Fernandez-Martinez et al., 2000). It happened in the course of the 1990s. Although the 5 known races, A to E, exhibited monogenic and dominant inheritance, this new $\mathrm{F}$ race, with the sunflower line LC-1093 as differential, showed additive dominant allelic reaction due to two loci with two types of epistasis. Based on the results of the FAO European Sunflower Network study conducted under conditions of natural and artificial infestationin different European countries in 1996-97, the most virulent $\mathrm{F}$ race was found in Turkey and it affected the important yield characters of sunflower (Shindrova et al., 1998).

However, a new broomrape race other than race $\mathrm{F}$ was observed in Spain and Turkey in recent years. The Turkish $\mathrm{F}$ race appears to be more virulent than the Spainish one and additionally there could be one or two more races than those positively known to be present in the region (Kaya, 2004). Although resistant and tolerant sunflower hybrids were planted, these cultivars became susceptible after couple 
of years due to high virulence of these new races. Furthermore, the areas in Trakya region of Turkey infested with the new races kept increasing the sunflower production acreage year after year until the figure exceeded $90 \%$ of the total arable land.

The broomrape problem was solved by introducing genetically resistant hybrids and IMI (imidazolinone) resistant cultivars in the sunflower production in Turkey. IMI resistance were discovered in wild sunflowers in USA and the cultivated herbicide-resistant lines were derived by using conventional backcross methods of breeding, within the framework of USDA sunflower breeding programs (Alonso et al, 1998; Al Khatib et al., 1998; Miller and Al Khatib, 2000; Miller, 2002). Resistant IMI hybrids and IMI Imazamox, Imazapyr post-emergence herbicide, together called the CLEARFIELD ${ }^{\circledR}$ System was developed by BASF Co. (Anonymus, 2003) and were widely used by farmers to controlg both $O$. cernua and other important weeds such as Xanthium strumarium L., Sinapis arvensis L., Chenopodium album L., Cirsium arvense (L) Scop., Convolvulus arvensis L., Avena spp., Datura stramonium, Amaranthus spp. in Turkey.

Intervix (Imazamox + Imazapyr, 33+15 g/l), manufactured by BASF Co., is the only registered herbicide in Turkey which, in the application dose of $1.25 \mathrm{l} / \mathrm{ha}$, controls both O. cernua and key weeds (Demirci and Kaya, 2003; Yucer, 2008). It was used successfully in the sunflower production since 2003. The Clearfield-applied acreage exceeded $30 \%$ of the sunflower production in Turkey in 2005. Sunflower growers preferred this system especially in the problem areas in which weeds esp. $X$. strumarium $L$. accompanied the broomrape, such as Trakya region, because it made the sunflower production profitable (Kaya et al, 2003). Additionally, the Clearfield system is effectively used in other countries too (Malidža, 2003).

Another solution for controlling both Orobanche and weeds is chlorsulfuron from SURE (sulfonyl urea) herbicide group, which was obtained by USDA and it works like the IMI resistance. Furthermore the SURE herbicides are cheaper than the IMI group and they control some weeds that the IMI herbicides do not. However, broomrape control by SURE herbicide is less efficient than by IMI herbicides (Kaya et al, 2007). Therefore, this system could be combined with IMI resistance to broaden the range of control of different weed species as well as with broompraperesistant hybrids in broomrape areas of Turkey.

\section{MATERIAL AND METHOD}

The research was conducted in Edirne, Tekirdag and Kirklareli in Trakya, Turkey. In the first part of the study, agronomic measures (types of hybrids planted, weed management, broomrape control level and efficiency) were observed and yield results were obtained directly from 202 fields that had problems with broomrape and major weeds. Sunflower farmers planted genetically resistant hybrids (such as P-4223 from Pioneer Seed Company) and IMI resistant hybrids (such as Sanay from Syngenta Seed Company) and also nonresistant hybrids (such as Sanbro from 
Syngenta Seed Company). To control broomrape in IMI resistant hybrids, they applied Intervix (imazamox + imazapyr $(33+15 \mathrm{ml} / \mathrm{l})$, at the dose of $1.25 \mathrm{l} / \mathrm{ha}$ at 8 10 leaves stage, for post-emergence control of both broomrape and major weeds. In nonresistant hybrids such as Sanbro, they used Oroban (imazapic (10 g/l), applying 0.4 1/ha at a 10-day interval, at 6-8 leaves and 10-12 leaves stages).

In the second part of the study, the experiments were conducted in Edirne, Tekirdag and Kirklareli locations in Trakya region again. The experimental design was a complete randomized block design with three replicates. Three-row plots were $7 \mathrm{~m}$ long, with $70 \times 35-\mathrm{cm}$ plant spacing. Three sunflower hybrids, the genetically resistant hybrids P-4223, the IMI resistant hybrid Sanay and the susceptible hybrid Sanbro, were used in the research. For broomrape and weed control in the experiments, Intervix (imazamox + imazapyr $(33+15 \mathrm{ml} / \mathrm{l}), 1.25 \mathrm{l} / \mathrm{ha}$ dose) was applied post-emergence in Sanay at 6-8 leaves stage. In the plot with the nonresistant hybrid Sanbro, Oroban was used for broomrape control. Hoeing was performed to control weeds in Sanbro and P-4223 plots. The check plots were not treated. Seed yield $\left(\mathrm{kg} \mathrm{ha}^{-1}\right)$ of the hybrids was measured and compared to establish yield differences. The JUMP statistical package was used for statistical analysis.

\section{RESULTS AND DISCUSSION}

Almost all sunflower farmers in Turkey prefer hybrid seeds. Due to broomrape problem in Trakya region of Turkey, genetically broomrape resistant or IMI resistant hybrids had to be grown in the region. On the other hand, the CLEARFIELD system (IMI resistant hybrid + postemergence applied IMI herbicide) gained increasing popularity year after year in the region due to its effective weed control. Because of this situation, the IMI resistant hybrid Sanay was observed in the research as the most preferred hybrid $(40.5 \%)$ in the region. The susceptible SANBRO (30.7\%) and genetically resistant P-4223 (28.7\%) followed Sanay regarding the commercial acreage (Table 1).

Table 1: Seed yields obtained by the 202 sunflower producers participating in the research

\begin{tabular}{lccc}
\hline \multirow{2}{*}{ Cultivar } & \multicolumn{3}{c}{ Treatment / Yield $\left(\mathrm{kg} \mathrm{ha}^{-1}\right) /$ Frequency } \\
& $\begin{array}{c}\text { Imazamox }+ \text { Imazapyr } \\
(35+15 \mathrm{~g} / \mathrm{l}) 1.25 \mathrm{l} / \mathrm{ha}\end{array}$ & $\begin{array}{c}\text { Imazapic } \\
(10 \mathrm{~g} / \mathrm{l}) 0.4+0.4 \mathrm{l} / \mathrm{ha}\end{array}$ & None \\
\hline Sanay (IMI resistant) & $2209.1(64)$ & $2212.8(9)$ & $2057.6(9)$ \\
Sanbro (Susceptible) & - & $2218.4(35)$ & $2031.8(27)$ \\
P-4223 (Broomrape resistant) & - & - & $2152.2(58)$ \\
\hline
\end{tabular}

Based on the seed yields presented in Table 1, Imazapic-applied Sanbro was in the first place, while Imazapic-applied Sanay, broomrape resistant P-4223, non herbicide-applied Sanbro and Sanay followed it. Broomrape susceptibility rate differed in the observed fields. When broomrape and major weeds were a big problem in the fields, farmers preferred to post-emergence apply Intervix (35+15 g/l Imazamox + Imazapyr) at the dose of $1.251 /$ ha to control both of them. When the field had only a small problem with broomrape (about 2 and 3 broomrapes per sun- 
flower plant) and weeds, farmers preferred two Oroban (10 g/l Imazapic) 0.4 1/ha doses because it was cheaper than Intervix. When there were no broomrape or weeds, farmers did not apply any herbicide and limited the control to hand hoeing and between-rowcultivation with hoeing machines.

The farmers mostly preferred the hybrid P-4223 in weed-free fields but high broomrape frequency (5.9 broomrapes/plant). In was also observed that some farmers applied Trifluralin and Aclonifen in combination with hand hoeing to control weeds in their fields. In fields free of broomrape and weeds, farmers preferred the hybrid Sanbro. If they found few broomrapes in their fields, they applied Imazapic. For a low weedinfestation, they control them with Trifluralin and Aclonifen or hoeing.

The second part of the study, with different broomrape frequencies (O. cernua, on average 4.9-7.2 broomrapes per plant) and high weed density (Sinapis arvensis, Convolvulus arvensis, Chenopodium album, Xanthium strumarim, Cirsium arvense), was conducted in three locations (Edirne, Tekirdag and Kirklareli, Table 2). Major weeds were removed from all plots by hoeing, except in the controls and plots treated with Imazamox+Imazapyr for Sanay and Imazapic for Sanbro and Sanay.

Based on the average values of the three locations, highest yields were obtained with the hybrid Sanay and Imazamox+Imazapyr aplication, most probably due high herbicide efficiency on bromrape and major weed in the research fields (Table 2). In Tekirdag, the highest yield was obtained with the hybrid P-4223, $3507.8 \mathrm{~kg} \mathrm{ha}^{-1}$, which was also in the second place regarding the average values.

Table 2: Yield of sunflower hybrids and treatments applied in three locations

\begin{tabular}{llcccc}
\hline \multirow{2}{*}{ Cultivar } & \multirow{2}{*}{ Treatment } & \multicolumn{4}{c}{ Yield $\left(\mathrm{kg} \mathrm{ha}^{-1}\right)$} \\
\cline { 2 - 5 } & & Edirne & Tekirdag & Kirklareli & Mean \\
\hline Sanay (IMI resistant) & Imazamox+Imazapyr & $3270.0 \mathrm{~A}$ & $3331.3 \mathrm{~A}$ & $2686.0 \mathrm{~A}$ & $3095.8 \mathrm{~A}$ \\
Sanay (IMI resistant) & Imazapic & $2431.5 \mathrm{~B}$ & $2909.0 \mathrm{AB}$ & $1553.5 \mathrm{BC}$ & $2298.0 \mathrm{BC}$ \\
Sanbro (Susceptible) & Imazapic & $1322.5 \mathrm{C}$ & $2108.8 \mathrm{C}$ & $2098.0 \mathrm{AB}$ & $1843.1 \mathrm{D}$ \\
P-4223 (Gen. ses.) & None & $2590.8 \mathrm{~B}$ & $3507.8 \mathrm{~A}$ & $2168.3 \mathrm{AB}$ & $2755.6 \mathrm{AB}$ \\
Sanay (IMI resistant) & Untreated Control & $2381.3 \mathrm{~B}$ & $2408.8 \mathrm{BC}$ & $1274.8 \mathrm{C}$ & $2021.6 \mathrm{C}$ \\
Sanbro (Susceptible) & Untreated Control & $1171.0 \mathrm{C}$ & $1878.0 \mathrm{C}$ & $1915.3 \mathrm{BC}$ & $1654.8 \mathrm{D}$ \\
\hline \multicolumn{2}{c}{ Average } & 2194.5 & 2690.6 & 1949.3 & 2278.2 \\
\multicolumn{2}{c}{ LSD (kg ha $\left.{ }^{-1}\right)$} & 437.0 & 636.0 & 678.0 & 384.0 \\
$\mathrm{CV}(5 \%)$ & 13.4 & 16.3 & 13.5 & 16.7 \\
\hline
\end{tabular}

\section{CONCLUSIONS}

It was concluded on the basis on these results that when there is a low density on weeds and broomrape in the sunflower field, genetically resistant sunflower cultivars such as P-4223 could be advised along with conventional weed control methods. Similarly, in fields with low weed density, susceptible cultivars such as Sanbro could be advised, with Imazapic for broomrape control. However, in fields with high broomrape and weed densities, planting IMI resistant hybrids along with Ima- 
zamox+Imazapyr application for weed and broomrape control seems an effective solution based on this study. On the other hand, Imazapic application is not more profitable or effective than Imazamox+Imazapyr application.

\section{REFERENCES}

Anonymus, 2003. CLEARFIELD ${ }^{\circledR}$ Production System. BASF Company. www.clearfieldsystem.com

Aćimović, M. 1980. Physiological races of Orobanche cumana Wallr. on sunflower in Yugoslavia. In: Proc. $9^{\text {th }}$ Int. Sunflower Conference. Torremolinos, Spain. June, 8-13. pp. 162-167.

Al-Khatib, K., Baumgartner, J.R., Petersen, D.E. and Curie, R.S., 1998. Imazethapyr resistance in common sunflower (Helianthus annuus L.). Weed Science 46: 403-407.

Alonso, C., 1996. New highly virulent sunflower broomrape (Orobanche cumana Wallr.) phenotypes in Spain. Advances in parasitic plant research. $6^{\text {th }}$ International Parasitic Weed Symposium. April 16-18, 1996. Cordoba, Spain.

Alonso, L.C., Rodriquez-Ojedo, M.I., Fernedez-Escobar, J., Lopez-Ruiz-Calero, G., 1998. Chemical control of broomrape (Orobanche cernua Loeffl.) in sunflower (Helianthus annuus L.) resistant to imazethapyr herbicide. Helia 29: 45-54.

Bulbul, A., Salihoglu, M., Sari, Ç., and Aydin, A., 1991. Determination of broomrape (Orobanche cumana. Wallr.) races of sunflower in the Thrace region of Turkey. Helia. 14(15): 21-26.

Demirci, M., Nemli, Y. and Kaya, Y., 2003. Effect of soil temperature on Orobanche cernua Loeffl. growing stages and control strategies. Proc. European Weed Research Society (EWRS) $7^{\text {th }}$ Mediterranean Symposium, 6-9 May. Cukurova University, Adana, Turkey. pp. 151-152.

Domingez, J., J.M. Melero-Vara, J. Ruso, J.F. Miller and J.M. Fernanadez-Martinez. 1996. Screening for resistance to broomrape (Orobanche cernua) in cultivated sunflower. Plant Breeding. 115: 201-202

Fernandez-Martinez, J.M., Melero-Vara, J., Munoz-Ruz, J., Ruso, J. and Domingez, J., 2000. Selection of wild and cultivated sunflower for resistance to a new broomrape race that overcomes resistance of the Or $_{5}$ gene. Crop Science. 40 (2): 550-555.

Gagne, G., Roeckel-Drevet, P., Grezes-Besset, B., Shindrova, P., Ivanov, P., Grand-Ravel, C., Vear, F., Labrohue, D., Charmet, G. and Nicolas, P., 1998. Study of variability and evolution of Orobanche cumana populations infesting sunflower in different European countries. Theoretical and Applied Genetics 96: 1216-1222.

Jan, C.C., Ruso, J.A., Munoz-Ruz, J. and Fernandez, J.M., 2000. Resistance of sunflower (Helianthus) perennial species, interspecific amphidiploids and backcross progeny to broomrape (Orobanche cumana Wallr.) races. Proceedings of $15^{\text {th }}$ Int. Sunflower Conf. Toulouse, France. June 12-15. J: 14-19.

Kaya, Y., 2003. Ayçiçeginde Orobans ve Mucadelesi. Tarim Istanbul. 84: 26-28.

Kaya, Y., Evci, G., Demirci, M., Pekcan, V. and Gucer, T., 2003. The Breeding and Development of Hybrids and Lines Resistant to Imidazolinone Herbicide. Proceedings of $5^{\text {th }}$ Turkish Field Crops Congress, Diyarbakir. October 13-17. pp. 163-168.

Kaya, Y., Evci, G., Durak, S., Pekcan, V., Gucer, T. and Yilmaz, I.M., 2007. The Breeding of Sulfonyl Urea (SU) Herbicide Resistant Sunflower Inbred Lines. Proceedings of $7^{\text {th }}$ Turkish Field Crops Congress, Erzurum. June 25-29. pp. 366-369.

Malidža, G., Jocić, S. and Škorić, D., 2003. Weed and broomrape (Orobanche cernua) control in Clearfield in sunflower. Proc. European Weed Research Society (EWRS) $7^{\text {th }}$ Mediterranean Symposium, 6-9 May. Cukurova University, Adana, Turkey. pp. 51-52.

Melero-Vara, J.M., Domingez, J. and Fernanadez-Martinez, J.M., 1989. Evaluation of differential lines in a collection of sunflower parental lines for resistance to broomrape (Orobanche cernua) in Spain. Plant Breeding. 102: 322-326.

Mihaljčević, M., 1996. Distribution and virulence of Orobanche populations in Yugoslavia. Symposium on Breeding of Oil and Protein Crops, August 5-8, Zaporozhye, Ukraine. pp. 134-136.

Miller, J.F. and Al-Khatib, K., 2000. Development of Herbicide Resistant Germplasm in Sunflower. Proc. $15^{\text {th }}$ Int. Sunflower Conf. Toulouse, France. June 12-15 pp. 37-41. 
Miller, J.F., 2002. Cross-Resistance of Two Sulfonylurea-Resistant Sunflower Sources to Selected Als Herbicides. Proceedings of Sunflower Research Workshop, January 24, Fargo, ND, USA

Ozhatay, N. 1973. Türkiye'nin Trakya Bölgesi ve Istanbul cevresindeki Orobanche türleri. Doktora Tezi. Istanbul Üniversitesi Eczacilik Fakültesi. Istanbul. Yayin No: 46.

Pacureanu-Joita, M., Vranceanu, A.V., Soare G., Marinescu A. and Sandu, I., 1998. The evaluation of the parasite-host interaction the system (Helianthus annuus L.) (Orobanche cumana Wallr.) in Romania. Proceedings of $2^{\text {nd }}$ Balkan Symposium on Field Crops. 16-20 June, 1998. Novi Sad, Yugoslavia. pp. 153-155.

Ruso, J., Sukno, S., Melero-Vara J.M. and Fernanadez-Martinez, J.M., 1996. Screening of wild Helianthus species and derived lines for resistance to several populations of Orobanche cernua. Plant Disease. 80: 1165-1169.

Shindrova, P., Ivanov, P. and Nikolova, V., 1998. Effect of broomrape (Orobanche cumana Wallr.) intensity of attack on some morphological and biochemical indices of sunflower (Helianthus annuus L.). Helia 21(29): 55-62.

Sukno, S., Melero-Vara J.M. and Fernanadez-Martinez, J.M., 1999a. Reproductive behavior and broomrape resistance in interspesific hybrids of sunflower. Plant Breeding 117: 279285.

Sukno, S., Melero-Vara, J.M., and Fernanadez-Martinez, J.M., 1999b. Inheritance of resistance to Orobanche cernua Loefl. in six sunflower lines. Crop Science 39: 674-678.

Uludere, O.A., Salihoglu, M., Sari, C. and Cukadar, B., 1988. Trakya'da Yeniden Gorulen orobansin (Orobanche cumana. Wallr.) Irk tespiti ile dunyada ve Turkiye de uretilen baslica ayçiçegi çesitlerinin ve bazi hatlarin dayaniklilik durumlari. Sonuc Raporu. Trakya Tarimsal Arastirma Enstitusu. Edirne, Turkey.

Vranceanu, A.V., Tudor, V.A., Stonescu, F.M. and Pirvu, N., 1980. Virulence groups of broomrape Orobanche cumana Wallr.) differential hosts and resistance sources and genes in sunflower. Proc. of $9^{\text {th }}$ Int. Sunflower Conference. Torremolinos, Spain. June, 8-13 pp. 74-81.

Yücer, M., 2008. Tarim Ilaclari. Registered Agrochemicals in Turkey. Hasad Yayincilik. 355 p.

\title{
SITUACIÓN DE Orobanche cernua Loefl. Y DE LAS MALEZAS EN LA PRODUCCIÓN DE GIRASOL EN TURQUÍA
}

\author{
RESUMEN
}

El jopo (O. cernuua) es uno de los más serios obstáculos en la producción de girasol en Turquía y Europa oriental. Estudios previos demostraron que herbicidas del tipo de las imidazolinonas (IMI), aplicados al girasol resistente a las IMI, controla efectivamente el jopo por la rápida absorción, translocación y acumulación en las raíces adjuntas del parásito. Sin embargo, el nivel de susceptibilidad de las variedades no resistentes del girasol a los herbicidas ha sido un obstáculo en la aplicación de estos productos químicos. Se realizaron estudios con variedades susceptibles de girasol. Pero los mejores resultados se obtuvieron a partir de un único tratamiento foliar de Imazamox (35 g/l)+imazapyr (15 g/1), 43, 75+18, 75 g/hectárea aplicado sobre plantas de girasol resistentes a los IMI en el estadio 8-10 hojas verdaderas. El tratamiento causó graves daños a las plantas susceptibles de girasol, pero ninguno a las de las variedades resistentes a los IMI, y controló completamente O. cernua, lo cual provocó un aumento significativo de la producción de granos de girasol sobre el control no tratado. Además, el mismo tratamiento controló malezas claves que perjudican seriamente la producción de girasol. El jopo (O. cernua) y las malezas han reducido gravemente el rendimiento del girasol, en el área de producción, con un alto impacto económico. Pero el uso de híbridos resistentes y tolerantes a los IMI suprimió y redujo eficazmente la población de malezas y la epidemia en los últimos años. 


\title{
POINT SUR l'Orobanche cernua Loefl. ET SUR LES ADVENTICES DANS LA PRODUCTION DE TOURNESOL EN TURQUIE
}

\author{
RÉSUMÉ
}

L'Orobanche (O. cernua) est l'un des obstacles les plus sérieux dans la production de tournesol dans l'ensemble de la Turquie et de l'Europe de l'Est. Des études préalables ont montré que les herbicides à base d'imidazole (IMI) appliqués sur du tournesol résistant permettent un contrôle efficace d'Orobanche cernua par absorption, translocation et accumulation rapides dans la racine parasitée.

Cependant, le niveau de sensibilité des tournesols non tolérants à ces herbicides a été un obstacle pour leur application. Des études préliminaires ont été menées avec de telles variétés: pour un traitement foliaire unique d'Imazamox (35 g/l) et d'Imazapyr (15 g/l), soit $43.75+18.75 \mathrm{~g} / \mathrm{ha}$; les meilleurs résultats ont été obtenus sur des plantes résistantes, au stade 8-10 feuilles.

Le traitement a causé de sérieux dommages sur les lignées sensibles de tournesol mais aucun dégât n'a été observé sur les variétés IMI résistantes et a permis de contrôler complètement le parasite $O$. cernua. La conséquence positive a été une hausse significative du rendement grain par rapport au témoin non traité.

Simultanément le même traitement a détruit efficacement l'ensemble des mauvaises herbes qui endommageaient sérieusement la production. L'Orobanche (O. cernua) et les adventices ont en effet colonisé certaines zones de production à fort intérêt économique entraînant une baisse considérable du rendement. L'utilisation de tournesols tolérants à l'IMI et à l'Orobanche a permis la diminution des populations d'adventices et la dispersion du parasite ces dernières années.

Paper presented at the International Symposium on broomrape (Orobanche spp. ) in sunflower, organized by the Trakya Agricultural Research Institute, held in Antalya, Turkey, from November 30 to December 3, 2008. 